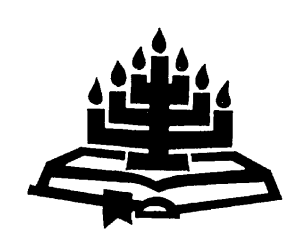

\title{
'n Diskoers oor eskatologie en promissioterapie by vroue na die verlies van 'n eggenoot
}

\author{
A. de Beer \& J-A. van den Berg \\ Departement Praktiese Teologie \\ Universiteit van die Vrystaat \\ BLOEMFONTEIN \\ E-pos: adebeer@compuking.co.za \\ vdbergja@ufs.ac.za
}

\section{Abstract \\ A discourse on eschatology and promissiotherapy with women after the loss of a husband}

The central metaphor "discourse" is used in this research because it links with the narrative approach. This discourse is founded in practical theology and researched from postmodernity as paradigm and social constructionism as epistemological point of departure. The research is placed within the narrative hermeneutic approach and principles underlying participatory action research, as part of qualitative research methodology, are portrayed. The discourse is informed by using mechanisms of the narrative approach. Women, affected by the loss of a husband, constructed their stories during the pastoral therapeutic dialogue and their discourses on heaven are portrayed in verbatim conversations. The prospect of eschatology and promissiotherapy, to understand and interpret the experience of mourning and to facilitate hope and consolation, is explored. The concept eschatology emphasises the Christian aspect and deals with the actual and not just the ultimate. Promissiotherapy deals with the promises that are concerned with the beginning and the end or, in other words, the eschatology. The prospect of eschatology and promissiotherapy, to understand and interpret the experience of mourning and to facilitate hope and consolation, is explored. In this discussion the women's portrayal of life hereafter and the role it can play to offer hope and consolation are illustrated. 


\section{Opsomming}

\section{'n Diskoers oor eskatologie en promissioterapie by vroue na die verlies van 'n eggenoot}

Die metafoor "diskoers" word in hierdie navorsing verkies aangesien dit resoneer met die narratiewe benadering. Die ondersoek is prakties-teologies begrond en vanuit postmoderniteit as paradigma nagevors met sosiaal-konstruksionisme as epistemologiese vertrekpunt. Die navorsing is binne die narratiefhermeneutiese navorsingsbenadering geplaas en beginsels onderliggend aan deelnemende aksie-navorsing is as deel van kwalitatiewe navorsingsmetodiek gebruik. Die ondersoek is deur die gebruik van meganismes van die narratiewe benadering geïnformeer. Tydens die pastoraal-terapeutiese gesprekvoering het vroue hulle verhale gekonstrueer en hulle diskoerse oor die hemel word in verbatimuittreksels aangehaal. Die moontlikheid om die belewenis van rou te verstaan en te interpreteer sowel as om hoop en vertroosting met behulp van eskatologie en promissioterapie te fasiliteer, word ondersoek. Eskatologie beklemtoon die Christelike aspek en handel met die eintlike en nie slegs met die uiteindelike nie. Promissioterapie handel met die beloftes wat gemoeid is met die begin en die einde, met ander woorde, die eskatologie. In hierdie bespreking word die vroue se siening van die lewe hierna en die rol wat dit kan speel om hoop en vertroosting te bied, toegelig.

\section{Inleiding}

Hierdie navorsing fokus op die kongruente pastorale belewenis en hantering van rousmart en pyn van 'n aantal getroude vroue na die verlies van hulle eggenote deur die dood. Dit is belangrik om te onthou dat die dinamika van verdriet geraak word deur die emosionele verbintenis met die geliefde. "The more emotionally attached the griever was, the greater his/her vulnerability and the more intense the pain of longing and hurt." (Louw, 2008:549.)

Die bekende digter Totius (J.D. du Toit) het self die pyn van verlies na die dood van geliefdes ervaar, wat aanleiding gegee het tot 'n aantal gedigte uit sy pen. Sy gedigte weerspieël diepere gevoelens wat na die dood van 'n geliefde ervaar word. Spesifieke fragmente uit Totius se gedigte is gekies, omdat dit ooreenstemmende ervaring met die vroue se rouproses en pyn uitbeeld wat in die navorsing gedokumenteer word.

Aangesien hierdie gedigte godsdienstig van aard is en inpas by die tema van hierdie diskoers, word grepe daaruit as "voertuig" voor- 
gehou om hierdie studie metafories saam te bind. Totius se vermoë om sy ervarings in taal uit te beeld pas ook binne die narratiewe paradigma, wat ' $n$ aanvoeling vir tekste, woorde en betekenis het. Sy gedigte skep 'n bewustheid van die rouproses asook die eskatologie en promissioterapie wat daarin vervleg is. Eskatologie gaan om "... die begin in die einde: die nuwe skepping en die triomf van die opstanding oor die dood" (Louw 1999:15). Tydens die pastorale ontmoeting met gespreksgenote is daar gelet op die rol wat eskatologie en promissioterapie in die fasilitering van hoop en vertroosting kan speel. Promissioterapie word gesien as hoopterapie aan die mens in die soeke na lewensin (Louw, 1999:14). In die bespreking van die begrippe eskatologie en promissioterapie kom die medenavorsers se unieke voorstelling van die lewe hierna onder die loep. Die diskoers moet nie gesien word as 'n uitgewerkte stelsel van denke oor die hiernamaals nie, maar as 'n gesprek om die verskillende sienswyses van die gespreksgenote in hierdie proses te verwoord. Dit kan bydra om die begrip van eskatologie en promissioterapie met betrekking tot hoop en vertroosting ná die verlies van 'n geliefde te verhelder.

'n Diskoers oor die verband tussen eskatologie, promissioterapie en die rouproses word na aanleiding van gegewens uit die Skrif en ander resente beskikbare bronne wat sal bydra tot die verstaan en interpretasie van hierdie inligting, gevoer. 'n Skakeling met die praksis word weergegee ingevolge inligting uit die sienings van gespreksgenote. Die "practical wisdom"-model van Browning (1991:34-39), waarin van 'n sirkulêre beweging tussen praktyk en teorie gebruik gemaak word, verwoord die skryftrant wat die aard van die gesprek van die navorsing orden. As uitdrukking hiervan neem die navorser die verantwoordelikheid om, in navolging van Van den Berg (2004: 183-206), die metodologie te administreer. Dit word gedoen aan die hand van die stemme van vroue wat met stemme uit die literatuur verweef word.

\section{Probleemsamehang en agtergrond}

Die persoonlike verlies van my eggenoot het aanleiding gegee tot hierdie diskoers oor die probleem om na die verlies van 'n lewensmaat weer hoop en vertroosting te vind. Vrae wat na die dood van 'n geliefde ontstaan behels onder andere vrae oor hoekom die persoon moes sterf, waar die gestorwene nou is, sowel as vrae oor die opstanding uit die dood (Marais, 1999:3; Steyn, 2000:31). Die volgende fragmente impliseer hierdie soeke na antwoorde. 
Janie:

Hoekom moes hy nou sterf? Is daar 'n lewe hierna?

Sarie:

Waar is hy nou? Is hy al by die Here?

Belinda:

Wat nou? Waar vind mens vertroosting?

Uit sy gedig "Ek graaf met my gedagtes" blyk dit metafories asof Totius ook met vrae rondom die pyn van verlies geworstel het. Die volgende fragment skep die indruk dat daar 'n soeke na antwoorde is.

Ek graaf met my gedagtes

in die geheimenis,

en soek of daar geen antwoord

op al my raaisels is (Totius, 1933:51).

Vrae van die gespreksgenote oor die toekomstige lewe of die lewe hierna beklemtoon hulle bepeinsing oor en persepsie van die hemel. Daar word gesoek na perspektiewe wat moontlik weer hoop en vertroosting kan bied. Om in die hemel herenig te word, bied vertroosting (Smit, 2000:11; Kübler-Ross \& Kessler, 2005:110; Gous, 2005: 174). Hierdie verlange in die teenswoordige na die toekomstige lewe weerspieël 'n eskatologiese perspektief. Dit het die diskoers oor eskatologie en promissioterapie aangewakker en my laat wonder oor die hoop en vertroosting wat dit ook ander vroue kan bied wanneer hulle 'n eggenoot verloor.

\subsection{Navorsingsuitdagings}

'n Narratief-pastorale ontdekkingstog is saam met drie vroue wie eggenote aan die dood afgestaan het, onderneem. Hierdie vroue is op grond van hulle belewenis na die verlies van 'n lewensmaat gekies. Aangesien hierdie navorsing pastoraal van aard is, word op Christenvroue en hulle eskatologiese siening gefokus. Daar is op die belewenis van hoop en vertroosting gefokus - 'n fokus wat voortvloei uit 'n persoonlike begrip van eskatologie en promissioterapie in die eerste jaar na die verlies van 'n eggenoot. Die eerste jaar is gekies, omdat die pyn van die verlies en die soeke na antwoorde in hierdie periode baie intens beleef word (Van Niekerk, 2002:24; Kübler-Ross \& Kessler, 2005:203; Endres, 2009:209). Meelewing met die ervarings van hierdie drie vroue het geboorte gegee aan die 
idee dat eskatologie en promissioterapie hoop en vertroosting by hulle kan fasiliteer.

\subsection{Doel van die diskoers}

Die doel van die diskoers oor eskatologie en promissioterapie is om met behulp van fasiliterende interaksie (terapie) in staat te wees om die vroue te bemagtig om hoop en vertroosting in hulle rouproses te ontdek. Diepere kwessies in die mens se lewe word tydens terapie ontbloot en bespreek met die doel om 'n helende ondervinding te fasiliteer. Terapie is 'n proses waarin die terapeut en 'n persoon die ervaring van die persoon bespreek in die hoop dat 'n positiewe verandering in die persoon se lewe bewerkstellig word (Lynch, 1997: 354; Botha, 2007:7). Dit vind plaas met die spesifieke doel om die persoon se selfverstaan te verander. Die gespreksgenoot ervaar persoonlike groei deur die alternatiewe storie wat in die terapeutiese proses tot stand kom. Daar moet positiewe verandering in 'n persoon se lewensverhaal plaasvind. Dit impliseer nie gedragsverandering nie, maar wel dat nuwe betekenis aan die rouproses gegee word.

\subsection{Navorsingsverwagtings}

Die uiteensetting van die navorsingsverwagtings fokus op wat moontlik in die diskoers bereik gaan word, waarom die ondersoek belangrik is en die bydrae daarvan tot die studieveld.

- Die vroue se vertolking van hoop en vertroosting speel 'n rol in die rouproses.

- Die vooronderstelling is dat promissioterapie ' $n$ rol speel in die skep van hoop en vertroosting na die verlies van 'n geliefde.

- Hoop op die opstanding uit die dood hou implikasies in vir die daaglikse bestaan van die bedroefde.

- Christenvroue, vanweë hulle spesifieke spirituele agtergrond, vind hoop en vertroosting in die wete dat hulle geliefdes in die hemel is.

- Die vroue se persepsie en konstruering van hulle voorstelling van die lewe hierna (hemel) wys die verband met hoop en vertroosting uit.

- Eskatologie en promissioterapie kan hoop en vertroosting by die vroue fasiliteer. 


\section{Aanwending van data}

Aangesien die studie 'n pastorale ondersoek behels, word in hierdie diskoers op die Skrif en toepaslike teksgedeeltes gefokus. Die Skrif word gesien as ' $n$ verhaal van mense se ervarings met God binne kultuur-historiese konteks (Louw, 1999:433). Die konteks omvat onderhoude met vroue binne die eerste jaar na die verlies van 'n eggenoot. 'n Houding van versigtigheid en sensitiwiteit in die vertolking van die deelnemers se perspektiewe hang saam met die begrip van die lewenskonteks van elke vrou. Deelnemers word gesien as unieke persone binne hulle persoonlike konteks. Die gespreksgenote se toestemming om inligting te gebruik, is verkry en hulle privaatheid en anonimiteit is deur die gebruik van skuilname beskerm en verseker.

\section{Metodologie}

Die studie is pastoraal van aard, met die mens as vertrekpunt en is derhalwe binne die praktiese teologie geposisioneer. In hierdie diskoers word die beginsels van interpretasie en regverdiging vir wetenskaplike navorsing vanuit die postmoderne perspektief verantwoord. Dit is paradigmaties vanuit postmoderniteit benader, aangesien die mens tans binne 'n postmoderne era leef (Brueggemann, 1993:ix; Botha, 2004:19; Van den Berg, 2006:164). Die term postmoderniteit verwys na 'n postmoderne tydperk, wat deur buigsaamheid en verandering gekenmerk word (Botha, 2004:19). Die voorafgaande era is verby en die mens word as ' $n$ unieke individu wat in hierdie era leef, erken (Müller, 1996:55). Postmoderniteit gaan daaroor dat omstandighede jou lewensbeskouing bepaal, maar dit erken ook sommige integriteitswaardes soos byvoorbeeld Bybeltekste, wat 'n invloed daarop het (De Beer, 2007:12). Meganismes soos dekonstruksie, kan met vrug binne postmoderniteit aangewend word en daar kan op kreatiewe wyse na die mens, kennis en lewensomstandighede gekyk word (Van Jaarsveld, 2001:101).

Die navorsing is binne die narratief-hermeneutiese navorsingsbenadering geplaas en kwalitatiewe navorsing, soos vergestalt in die metodologie van deelnemende aksie-navorsing, is verkies. Kwalitatiewe navorsing behels verskillende handelswyses vir die insameling van inligting (Swinton \& Mowat, 2006:29) en omvat 'n “... gewilligheid om betrokke te raak en betrek te word" (Sears, 1992:148). Kwalitatiewe onderhoude ontgin inligting oor menslike ervaring en gedrag, aangesien dit op belangstelling in mense se stories berus (Botha, 2001:15-17). Aangesien daar op verhale gefokus is vir die inwin en ordening van inligting, is die narratief-hermeneutiese bena- 
dering, sowel as die sosiale konstruksiediskoers verkies. "All the things that make up the psychological fabric of 'reality' - arise through social interaction over time." (Freedman \& Combs, 1996: 23.) Die mens se leefwêreld of realiteit word sosiaal gekonstrueer, deur taal saamgestel, georganiseer, deur narratiewe onderhou en behels geen wesenlike waarhede nie (Freedman \& Combs, 1996: 22). Die narratiewe benadering word daardeur gekenmerk dat "... daar nie iets soos objektiwiteit is nie, maar dat betekenis deur die sosiale konstruksie geskep word" (Putter, 2005:20). Dit gee aanleiding tot die vraag oor die rol wat die terapeut in die konstruering van die vroue se verhale speel - veral ten opsigte van hoop en vertroosting. In die narratief-sosiaal konstruksionistiese siening kan die realiteit nie objektief geken word nie, "... all we can do is interpret experience" (Freedman \& Combs, 1996:33). Daar kan hoogstens daarna gestreef word om gedrag te verstaan (De Beer, 2009:20). Die doel is die beskrywing, die ontdekking van sinvolheid en interpretering of rekonstruering van die interaksie in terme van die betekenis wat die gespreksgenote daaraan heg. Dit behels die veelvuldige betekenisse van lewe, deur mense gekonstrueer, binne die konteks van hulle taal en kultuur. Volgens Kotzé en Kotzé (1997:35) verteenwoordig taal nie mense se lewens nie, maar "... constitutes and shapes it". Medenavorsers vorm deel van die ondersoek en daarom is die metodologie onderliggend aan deelnemende aksienavorsing hier gepas.

Die geldigheid en betroubaarheid van die navorsing is geëvalueer aan die hand van waardes soos onder meer geloofwaardigheid, omvattendheid en konsekwentheid. Diskoerse is oorweeg en moontlike kontrasterende diskoerse is bevraagteken. By die interpretasie is gelet op verskillende verhale wat dieselfde tema beskryf. Deur herinterpretasie en herstrukturering van hierdie verhale is gepoog om verandering te fasiliteer, sodat die vroue hoop en vertroosting kan beleef en daardeur sin en betekenis in hulle lewens kan vind.

\section{Diskoersmerkers - perspektiewe op inhoud}

Eskatologie behels die persepsie terwyl promissioterapie die handeling is wat daarop ingebed is (De Beer, 2009:109). Die skakeling tussen die konsepte eskatologie en promissioterapie is die oorwinning van die opstanding. Promissioterapie verwoord die pastoraal geïnformeerde werkswyse waarin hoop gekonstrueer word sodat vertroosting en betekenis gevind word wat geloofsgroei stimuleer. Moore (2004:174) sê dat heilsterapie binne die pastoraal-terapeutiese gesprek as promissioterapie verklaar kan word. Deur die be- 
vordering van geloof en spiritualiteit met God as die Een wat heling bevorder, kan genesing plaasvind. Die vroue kan hierdeur die werklikheid op ' $n$ ander manier waarneem en verstaan. Dit blyk ook uit die volgende uittreksels waar drie vroue, sowel as die outeur, aan die woord gestel word:

Janie:

Dit het vir my gevoel asof God my vergeet het, maar nadat ek die geleentheid gekry het om vir berading te gaan, is ek weer op koers en besef ek dat Hy deur elke beproewing daar is om my te ondersteun.

Sarie:

Na my man se worsteling met emfiseem en sy heengaan wou ek niks van godsdiens af weet nie. Ek weet egter nou dat my lewe sonder my Skepper betekenisloos is.

Belinda:

My hele lewe lank was ek gelowig, maar nou weet ek werklik dat my lewe sonder die Here sinloos is. My man se dood en die geleentheid om daaroor te kan praat, het my weereens hoop gegee en my geloof versterk. Sonder die Here kan ek nie voortgaan in hierdie wêreld nie.

\section{Outeur:}

Geloof was vir my die anker in 'n stormagtige see van hartseer en verlorenheid. Ek het besef dat dood nie die einde is nie, maar dat daar 'n toekoms saam met Christus wag. Dit het my moed gegee om aan te gaan.

Die doel was om deur begeleiding die gespreksgenote tot geestelike volwassenheid te lei. Deur die ontwikkeling van hulle geloof het hoop by hulle ontstaan. Die dimensie van hoop as deel van 'n toekomsverwagting, is gestimuleer of opgewek. Die Christelike hoop is opstandingshoop en staan volgens Louw (2007:61) vas “... omdat dit geanker is in die trou van God".

\subsection{Eskatologie}

Die eskatologie word eerstens as diskoersmerker aangestip aangesien promissioterapie daaruit voortvloei, maar ook daarmee vervleg is. God se beloftes aangaande die heil van die mens is in Christus se kruis en opstanding vervul (Louw, 1999:2). Promissio- 
terapie gaan om die beloftes wat oor die begin in die einde handel, met ander woorde oor die eskatologie.

Die eskatologiese denke plaas die klem op die werklikheid, wat veel groter as die onderwerp is en nie eers deur ervaring 'n werklikheid word nie. God is met die wêreldgeskiedenis op pad en die opstanding is ' $n$ keerpunt daarin. Die hemelvaart bevestig sy kosmiese heerskappy, die "reeds" en "nog nie" van die eskatologie (Van Wyk, 2008:12-13). Die toekoms het hoop omdat God daar is en omdat sy koninkryk wat nou is, ook daar sal wees. Om te glo dat die lewe gered is, is om te glo in die hemel. Die hemel is niks anders as die liefdeslewe van God nie (Vosloo, 2001:1-6).

\title{
5.2 Vertroosting in die oortuiging dat daar 'n lewe hierna bestaan
}

Die Skrif is die bron van kennis ten opsigte van God se beloftes oor die toekomstige lewe saam met God. Die eskatologie hou verband met die vraag oor waarheen alles op pad is. Totius het ook nagedink oor die dood en die hiernamaals. Sy woorde in die gedig "Daar is geen dood", spreek daarvan:

\author{
Daar is geen dood \\ Wat lewe heet, is net die op en neer \\ as ons klein skuitjie al maar daal en klim; \\ en wat ons sterwe noem, is niks nie meer \\ as ons verdwyning op die gindse kim (Totius, 1933:56).
}

Dit kan gestel word dat die begrip hemel oor die aspek van die toekoms in die persepsie van die eskatologie handel. Die eskatologiese paradigma veronderstel die toekoms (hemel), maar die teenswoordige moet egter ook in gedagte gehou word, aangesien dit wesenlik deel van eskatologie is. Die vraag gaan nie net oor die toekoms nie, maar raak ook die wyse waarop ons elke oomblik leef. "Dit help ons om sin te vind in dit wat ons elke dag doen." (Conradie, 2006:14.)

'n Vraag oor die toekoms van die ontslapene ontstaan ook en waarom dit vir die vroue belangrik is ten opsigte van hoop en vertroosting. Vir die Christen is God se belofte van die opstanding uit die dood 'n antwoord hierop. Die vroue kan dus hulle hoop daarop bou. Daar is nie sekerheid oor die geestelike liggaam nie, maar dit is seker dat die persoon wat in Jesus glo, uit die dood na die lewe oorgegaan het. Onmiddellik ontstaan verdere vrae by die vroue oor 
die lewe na die opstanding uit die dood. In die volgende gespreksfragmente word sommige vrae wat uitgestaan het, aangetoon.

Janie:

Ek glo dat ons eendag sal opstaan uit die dood en weer by mekaar sal wees, maar sal ons mekaar ken? Waar gaan ons wees? Hoe sal ons lewe?

Sarie:

Dit klink vir my oneindig ver voor ons mekaar weer sal sien. Sal ons almal in die hemel wees en sal hy nog lief wees vir my? Gaan ons geeste wees? Gaan ons dieselfde persoonlikhede hê?

Belinda:

Sal hulle onthou wat hier op aarde gebeur het? Wat gaan ons vir mekaar beteken? Gaan ons nog lyk soos nou? Daar is so baie vrae waarop ek graag antwoorde sal wil hê.

\section{Outeur:}

Gaan ons mekaar nog liefhê soos hier op aarde? Sal ons weer take hê wat ons moet verrig? Sal ons nog eet, werk en slaap? Hoe gaan ons voel om mekaar weer te sien?

\subsection{Hoop}

Volgens Louw (2007:62) lê Christene se hoop in die wete dat Jesus aan die kom is. Hebreërs 6:18 bevestig dat hoop in die wete gesetel is dat God sy Woord gestand doen. Die grootste verskil wat in die Ou Testament en die Nuwe Testament rondom hoop gevind word, is dat verlossing deur Jesus Christus bewerkstellig is en daarom kan hoop as 'n eskatologiese seën ervaar word. Hoop kan gesien word as die dryfkrag en energie om ten spyte van moeilike omstandighede in die lewe voort te gaan. Eskatologiese hoop vorm die aksent van die vertroosting oor hulle verlies.

\subsection{Hoop en vertroosting}

Elke vrou se persoonlike paradigma sal 'n rol in die hantering van die verlies van 'n eggenoot speel. Die verwysingsraamwerk van waaruit die verlies hanteer word, behels onder andere persepsies, oortuigings en konteks. Enige mens hanteer verdriet volgens 'n eie siening en ervaring van die verlies. Volgens Van Niekerk (2002:25) is verdriet 'n emosie wat by die taak van rou voorkom. Dit behels ' $n$ 
poging om bevry of losgemaak te word van die verhouding wat bestaan het, en om emosionele kapitaal in nuwe produktiewe rigtings vir die gesondheid en welsyn van 'n toekomstige lewe in 'n gemeenskap te herbelê. "Our grief is as individual as our lives." (Kübler-Ross \& Kessler, 2005:7.) Hierdie intense emosies kan tot moedeloosheid lei en veroorsaak dat daar nie kreatief na oplossings gesoek word nie. Collins (2005:402) reken dat verlies 'n persoonlike en emosioneel-gelaaide gebeurlikheid is wat 'n mens ervaar. Waarin die vrou glo en hoe sy haar rol sien, sal haar persoonlike paradigma bepaal.

Verder loop die impak van die verlies nóú saam met die vertolking daarvan. Dit laat die vroue met die keuse of hulle wel sin in die lewe wil vind om te kan voortgaan. Die vraag oor die sin van die lewe kan slegs beantwoord word indien die vroue verstaan en die nodige begrip en insig het. Hestenes (2007:69) stel dit dat die mens nie kan leef "... without meaning and the systems of meaning provide people with an ability of making sense of the world". Hierdie betekenisstelsels is volgens hom gebaseer op waarhede wat betekenis gee, maar wat ook ons bestaan bevraagteken. Kultuur is hier ter sprake, aangesien elke persoon vanuit 'n spesifieke kultuurbeskouing 'n bepaalde wêreldbeeld internaliseer. Mense konstrueer hulle werklikheid soos hulle elke dag leef.

Troos lê daarin dat die mens weet waar en deur Wie 'n mens vertroos word. Gelowiges is kinders van God en Hy is daar vir elkeen. Pastorale begeleiding kan daartoe bydra dat die vroue bewus raak van die ware Vertrooster.

\subsection{Promissioterapie}

Promissioterapie kan onder andere ook as die teologie van die opstanding gesien word (Louw, 1999:426-427). Dit bind die terapie wesenlik aan 'n teologiese saak en help die pastor om tussen die psigologiese en pastorale momente in terapeutiese betrokkenheid te onderskei.

Promissioterapie het die effek dat dit die proses van geloofsgroei stimuleer en die dimensie van spiritualiteit bevorder. Die terapeutiese effek van promissioterapie is dat wat God in sy trou beloof het, geloof in die hart van die mens bewerkstellig en vastigheid en sekuriteit bied (Louw, 1999:518). Promissioterapie wil die mens op singewende waardes, sowel as op 'n sinontvangende lewensbron laat fokus. Hierdie fokus kan die mens in die daagliks praktyk van die lewe help om dankbaar te leef en hoopvol te sterf (Louw, 1999: 
14). Die teenwoordigheid van God, wat geloofsgroei bevorder en geloofsvolwassenheid wek, word as die lewensbron gesien. Dit word as 'n vorm van hoopterapie in mense se soeke na lewensin aangebied. Verder stimuleer dit ook geloofsvolwassenheid. Dit verteenwoordig met ander woorde die genesende omvang van herstel en groei.

Pastorale terapie, as promissioterapie, beteken dat God deur die Skrif doen wat Hy beloof en dat die mens glo, omdat die genadegawe van die Skrif tot gevolg het dat gelowiges reageer en getroos (parakleties) kan lewe (Louw, 1999:441). Die God-mensverhouding is die innerlike verhouding waarom dit in pastorale terapie gaan. Die doel van die terapeut is die herstel van hierdie verhouding in samehang met eksistensiële probleme wat die persoon mag ervaar (Moore, 2004:175).

\subsection{Verhalende benadering}

Die narratiewe benadering bied ruimte daarvoor dat persone en prosesse deel van die gesprek word (Botha, 2003:9). Die vroue se verhale ontstaan in samehang met die konteks waarin daar heelwat ander en groter stories bestaan. Die verhaal word in verhouding tot vele ander verhale in die vroue se lewens aan die orde gestel (Ganzevoort \& Visser, 2007:115). Dit gaan nie slegs om die bepaalde verhaal wat vertel word nie. Nadenke oor hoop en vertroosting is veral op die eksistensiële belewing daarvan gerig.

Volgens die narratiewe benadering is taal die meganisme waarmee verhale oorgedra word. Met die vertelling van verhale is die mens voortdurend besig om 'n leefwêreld te konstrueer (De Beer, 2007: 17). Taal, in die vertel van stories, is in hierdie ondersoek die werktuig waardeur betekenis en begrip aan lewensondervinding gegee word. Volgens Müller (2000:59) kry gespreksgenote se verstaan van hulle werklikheid in die gebruik van taal gestalte. In hierdie navorsing is die betrokke vroue aangemoedig om die opeenvolging van gebeure ten opsigte van die verlies van hulle eggenote, te herroep en na aanleiding van Müller se indeling te vertel. Terapeuties word daar in hierdie navorsing van Müller (2000:72-103) se gespreksbenadering gebruikgemaak, omdat die terapie die vorm van 'n gesprek aanneem. Die vyf bewegings word vervolgens kortliks in die dokumentering van die navorsingsproses aan die orde gestel. Terwyl 'n nie-wetende posisie gehandhaaf word, is die vroue as medenavorsers bygestaan om die volgende verhale, toegelig deur hulle eie stemme, aan die terapeut oor te dra: 


\section{- Noodverhaal}

Dit is die medenavorsers se verklarings van die pyn wat hulle ervaar. Die gespreksgenoot moet gehelp word om die noodverhaal te vertel (Müller, 2000:72).

Janie:

Dit is vir my baie moeilik om sy dood te aanvaar. Dit voel vir my asof daar niks is wat my kan vertroos nie. Ek kan nie daarmee vrede maak en dit aanvaar nie (dominante probleem).

Navorser:

Vertel my meer oor jou gevoelens wat jy ondervind en watter invloed dit op jou lewe het.

Janie:

Ek voel verlore en wonder waar hy nou is. Dit maak dat ek nie hoop het nie en dat die lewe nie meer betekenis vir my inhou nie.

Navorser:

Wat sal maak dat die lewe weer vir jou betekenis inhou? Janie:

As ek kan weet dat hy in die hemel is en vir my wag.

\section{- Verledeverhaal}

Dit is deel van medenavorsers se identiteit en vorm die basis waarop terapeuties met 'n persoon gewerk kan word. Die verlede verskaf die boustene vir rekonstruksie. Dit behels die geskiedenis van die noodverhaal wat vertel moet word (Müller, 2000:72).

Sarie:

Wat is daar tog oor vir my in die lewe wat my enigsins hoop kan gee? My steunpilaar in die lewe is weg.

Navorser:

Waarop het jy altyd jou hoop gebou? 
Sarie:

Ons het altyd saam stiltetyd gehou en daaroor gesels. Ons godsdiens was ons anker in die lewe. Ten spyte van sy siektetoestand het hy aan sy geloof vasgehou. Dit was nie vir hom 'n probleem om te praat oor doodgaan en die hemel nie. Hy het altyd gesê dat hy daar vir my sal wag. Dit is vir my vertroostend om te weet daar is 'n lewe hierna.

\section{- Verduisterde toekomsverhaal}

Metafories kan dit gesien word asof hierdie vroue tot op die punt van 'n berg geklim het en skielik is die wolke om hulle. Hulle kan nie die mooi landskap onder sien nie, maar hulle kan ook nie terugklim nie. Hulle voel vasgevang. Die toekomsverhaal word in die verledeverhaal ontdek (Müller, 2000:72-73). Die volgende fragmente uit gesprekke dui daarop:

Belinda:

Ek was bewus van die verganklikheid van die mens en die verlies van my man het ' $n$ vrees vir eensaamheid laat ontstaan. Ek het gewonder wat word nou van my vorentoe en het nie lus gehad om aan te gaan nie.

Navorser:

Wat is daar wat nog vir jou betekenis het en jou sal aanmoedig om voort te gaan?

Belinda:

$\mathrm{Al}$ is hy nie meer hier nie sou hy graag wou hê dat ek normaal moet aangaan met die lewe. Die idee dat ek nog iets vir hom kan doen, help. Ek sal graag wil hê dat hy nog trots op my moet wees.

\section{- Hervertelde verledeverhaal}

Dit behels ' $n$ heroriëntasie in terme van waardes wat herontdek word en waaruit 'n nuwe vertel van die verhaal moontlik word. Dit gaan oor die herstrukturering van die verledeverhaal met dieselfde stel feite om 'n meer aanvaarbare storie te skep. In die narratiewe benadering word die storie nie bloot as bron van inligting gebruik sodat 'n metode aangewend kan word om die persoon te verander nie (Senekal, 2005:72). Deur herhaaldelike herinterpretasie en herstrukturering vind verandering plaas en kan die vrou weer haar eie bestaan as betekenisvol beleef (Müller, 2000:73). 
Outeur:

Ek het besef dat hy nie meer hier is nie en dat die lewe steeds aangaan. Ek moet buite my veilige grense beweeg en uitreik na ander. Ek moet voortbou op dit wat ek gehad het en 'n nuwe sin van behoort ontwikkel.

\section{- Verbeelde toekomsverhaal:}

Deur middel van verbeelding moet 'n nuwe toekomsbeeld geskep word. Die terapeut nooi die gespreksgenoot uit om oor die toekoms en toekomsdrome te gesels. Toekomsverhale neem op 'n natuurlike manier vorm aan en is moontlik op grond van 'n herstruktureerde verledeverhaal (Müller, 2000:73).

Janie:

Die lewe het weer betekenis en ek kan weer my talente beoefen en my take geniet. Ek gaan weer naaldwerkklasse vir 'n klompie vroue gee.

Sarie:

Ek voel soos 'n vlinder wat met vreugde van blom na blom vlieg om die soet van die nektar te kry, maar ook om die blomme te bestuif. Ek besef nou dat ander my nodig het en dit voel asof die lewe weer betekenis gekry het.

Belinda:

Ek kan nou terugkyk na die pad waarlangs ek gestap het en dank die Here vir 'n goeie huwelik. Hy het my weer hoop gegee om aan te gaan.

Outeur:

Die moontlikheid om nuwe verhoudings te kan bou en vir ander van waarde te wees, het vir my 'n nuwe toekoms geskep. Daar sal dalk tye kom wanneer die verlies steeds oorweldigend sal wees, maar ek besef dat daar ander mense is wat my nodig het en wat ek kan ondersteun.

\section{Alternatiewe uitkomste}

Die gespreksgenoot ervaar persoonlike groei deur die alternatiewe storie, wat in die terapeutiese proses tot stand kom. Dit word onder andere gesien as betekenisvolle herformulering wat, soos Müller (1996:129) dit stel, "... nie noodwendig positief hoef te wees nie, die bedoeling is eerder dat die uitkoms positief moet wees ...". Daar 
moet positiewe verandering in 'n persoon se lewensverhaal plaasvind. Dit impliseer nie gedragsverandering nie, maar wel dat nuwe betekenis aan probleemgedrag gegee word.

Eskatologiese oortuigings lei tot 'n sekere lewensingesteldheid. Christenvroue kan die huidige bedeling positief benader in die wete dat Jesus Christus reeds (en steeds) Koning in die wêreld is. Die bevestiging van sy koningskap word in Openbaring 19:6 aangedui: "... Die Here ons God, die Almagtige, heers nou as koning". Vanuit hierdie oortuiging kan hulle in God se wêreld betrokke raak. Die mens beleef reeds die nuwe bedeling (nog onvolmaak) en sien uit na 'n meer volmaakte toekoms. Eskatologiese verwagtings word op hoop gebou. Hoop is gerig op die toekoms. Uit ons ervaring van die verlede en hede kan ons die toekoms verbeeldingryk sien. Dit word ook uitgebeeld in die woorde van Totius (1933:55) in "As ek oor die bleek-verlate sand":

As ek dan oor dié sand moet gaan,

Dan hou ek op dié spoortjies aan

Totdat ek, waar dit haas verswind, Hul albei eind'lik vind.

Eskatologiese hoop vir vroue wie die verlies van 'n eggenoot ervaar, word in die pastorale gesprek gekommunikeer. Promissioterapie beskik oor al die elemente waarvolgens hierdie hoop gefasiliteer kan word. Dit is dus van belang vir die ontwikkeling van 'n narratief-pastorale benadering by die hantering van rousmart by vroue.

\section{Samevatting}

Daar is deurgaans in gedagte gehou dat hierdie 'n narratiewe ondersoek is en daarom is medenavorsers wie deel is van die ondersoek, betrek en aangehaal. Die diskoers oor eskatologie en promissioterapie is aan die hand van die metaforiese meelewing met Totius verhelder. Daar is uitgewys dat die begrip eskatologie die Christelike aspek beklemtoon. God is met die wêreldgeskiedenis op pad en die opstanding is die keerpunt. Die eskatologie gaan ook oor die eintlike, en nie alleen oor die uiteindelike nie. Dit gaan daaroor dat God se beloftes aangaande die heil van die mens in Christus se kruis en opstanding vervul is. Die terapeutiese aksent dui daarop dat eskatologie die persepsie en promissioterapie die handeling behels. Promissioterapie vloei uit die eskatologie voort en is ook daarmee vervleg. Dit kan verder gestel word dat promissioterapie om die beloftes wat oor die begin in die einde handel, met ander woorde oor die eskatologie, gaan. Hoop bepaal die vroue se persoonlike 
paradigmas en is verbonde aan wat die vroue glo en hoe hulle hulle rolle sien. Dit laat ook die vroue met die keuse of hulle sin in die lewe wil vind. Troos lê daarin dat die mens weet waar en deur Wie hy/sy vertroos word.

\section{Geraadpleegde bronne}

BOTHA, A.C. 2004. 'n Gegronde studie oor seksuele molestering. Johannesburg: Randse Afrikaanse Universiteit. (Ongepubliseerde D.Litt. et Phil.proefskrif.)

BOTHA, J.A. 2003. Narratiewe pastorale egskeidingsmediasie: stories van hoop. Pretoria: Universiteit van Pretoria. (Ongepubliseerde Ph.D.-proefskrif.)

BOTHA, P. 2001. Die kwalitatiewe onderhoud as data-insamelingstegniek: sterk en swak punte. Journal of family ecology and consumer sciences, (29):1319.

BOTHA, S.W.J. 2007. Can marriage survive traumatic child death? A "narrative dance" towards an alternative discourse for spouses' emotional attachment through pastoral therapy. Bloemfontein: University of the Free State. (Unpublished Ph.D. thesis.)

BROWNING, D.S. 1991. A fundamental practical theology: descriptive and strategic proposals. Minneapolis: Fortress.

BRUEGGEMANN, W. 1993. Texts under negotiation: the Bible and postmodern imagination. Minneapolis: Fortress.

COLLINS, G.R. 2005. Die A tot $Z$ van berading: bybelse perspektiewe op probleemoplossing. Kaapstad: Struik Christelike Boeke.

CONRADIE, E.M. 2006. Lewe anderkant die dood? In gesprek oor die hoop op die opstanding uit die dood. Wellington: Lux Verbi.BM.

DE BEER, A. 2007. Afsluiting na die verlies van 'n kind - 'n narratiewe pastorale studie van 'n moeder(s) se belewenis. Bloemfontein: Universiteit van die Vrystaat. (Ongepubliseerde M.A.-verhandeling.)

DE BEER, A. 2009. Promissioterapie by vroue na die verlies van 'n eggenoot: ' $n$ pastoraal-narratiewe studie. Bloemfontein: Universiteit van die Vrystaat. (Ongepubliseerde Ph.D.-proefskrif.)

ENDRES, A. 2009. Getraumatiseerde adolessente se soeke na hoop: 'n pastorale model. Pretoria: Universiteit van Pretoria (Ongepubliseerde Ph.D.-proefskrif.)

FREEDMAN, J. \& COMBS, G. 1996. Narrative therapy: the social construction of preferred realities. New York: Norton.

GANZEVOORT, R.R. \& VISSER, J. 2007. Zorg voor het verhaal: achtergrond, methode en inhoud van pastorale begeleiding. Zoetermeer: Meinema.

GOUS, H. 2005. Om die ondraaglike te dra: vir mense wat die seer van dood, selfmoord of depressie beleef het. Vereeniging: Christelike Uitgewersmaatskappy.

HESTENES, M.E. 2007. Different perspectives of suffering and healing: an overview. Practical theology in South Africa, 21(3):68-85.

KOTZÉ, E. \& KOTZÉ, D.J. 1997. Social construction as a postmodern discourse: an epistemology for conversational therapeutic practice. Acta theologica, 17(1):27-50. 
KÜBLER-ROSS, E. \& KESSLER, D. 2005. On grief and grieving: finding the meaning of grief and through the five stages of loss. London: Simon \& Schuster.

LOUW, D.J. 1999. Pastoraat as vertolking en ontmoeting: 'n teologiese ontwerp vir 'n basisteorie, antropologie, metode en terapie. Nuwe hersiene uitgawe. Kaapstad: Lux Verbi.BM.

LOUW, D.J. 2007. Wow, God! Oor die verrassende binnepret van glo. Wellington: Lux Verbi.BM.

LOUW, D.J. 2008. Cura vitae. Wellington: Lux Verbi.BM.

LYNCH, G. 1997. The role of community and narrative in the work of the therapist: a postmodern theory of the therapist's engagement in the therapeutic process. Counselling psychologist, 10(4):353-363.

MARAIS, W. 1999. Ons dode lewe. Vierde uitgawe. Pretoria: Aktuapers.

MOORE, A.G. 2004. 'n Narratief-pastorale benadering in maatskaplike werk. Bloemfontein: Universiteit van die Vrystaat. (Ongepubliseerde Ph.D.proefskrif).

MÜLLER, J. 1996. Om tot verhaal te kom. Pretoria: RGN.

MÜLLER, J. 2000. Reis-geselskap: die kuns van verhalende pastorale gesprekvoering. Wellington: Lux Verbi.BM.

PUTTER, J.J.J. 2005. Diskoerse oor heling binne 'n narratief-pastorale benadering. Pretoria: Universiteit van Pretoria. (Ongepubliseerde Ph.D.proefskrif.)

SEARS, J.T. 1992. Researching the other/searching for self: qualitative research on (homo)sexuality in education. Theory into practice, 31(2):147156.

SENEKAL, D.P. 2005. Die funksionering van bybelse inhoude in 'n narratiefpastorale gesprek. Pretoria: Universiteit van Suid-Afrika. (Ongepubliseerde M.A.-verhandeling.)

SMIT, N. 2000. Wanneer 'n vrou treur. Wellington: Lux Verbi.BM.

STEYN, E. 2000. Die grafte jubel: kroniek van pyn en genesing ná die dood van 'n kind. Wellington: Lux Verbi.BM.

SWINTON, J. \& MOWAT, H. 2006. Practical theology and qualitative research. London: SCM.

TOTIUS. 1933. Passieblomme: verse van Totius. Bloemfontein: Nasionale Pers.

VAN DEN BERG, J.A. 2004. 'n Hoofstuk in die (auto)biografie van die predikant (pastor?). Acta theologica supplementum, 6:183-206.

VAN DEN BERG, J.A. 2006. 'n Verandering in tongval ...? 'n Verwoord(-beeld)ing van pastoraal teologiese perspektiewe. Praktiese teologie in SuidAfrika, 20(2):164-181.

VAN JAARSVELD, F.J. 2001. Die rol van Godskonsepte vir pastorale terapie: 'n konstrukteoretiese benadering. Bloemfontein: Universiteit van die Vrystaat. (Ongepubliseerde Ph.D.-proefskrif.)

VAN NIEKERK, R. 2002. Verlies, pyn en die verwerking daarvan: praktiese begeleiding vir mense wat die beproewing van die dood ervaar het en steeds deurleef. Vereeniging: Christelike Uitgewersmaatskappy.

VAN WYK, A. 2008. Teologiese strominge in die NG-opleiding aan die Teologiese Fakulteit, UP: in gesprek met prof. Julian Müller. http://www. ngkok.co.za/Artikels/JulianMullerEnOpstanding_AvanWyk.pdf Datum van gebruik: 11 Jul. 2008. 
VOSLOO, R. 2001. Wat God doen, laat ons na Hom verlang. http://www. communitas.co.za/leesrooster/nt/66Openbaring/Openbaring\%2022_621.htm Datum van gebruik: 11 Jul. 2008.

\section{Kernbegrippe:}

deelnemende aksie-navorsing

eskatologie

narratiewe pastoraat

promissioterapie

verlies van 'n eggenoot

\section{Key concepts}

eschatological

loss of a husband

narrative pastoral care

participatory action research

promissiotherapy 
